\title{
Pedagogical Challenges in the Teaching of N-Level 4 Economics
}

\author{
Letlhoname Boitumelo Nkwadipo \\ University of the Free State, Free State, South Africa \\ https://orcid.org/0000-0003-3802-2216 \\ Msebenzi Rabaza* \\ University of the Free State, Free State Province, South Africa \\ https://orcid.org/0000-0003-2219-6131
}

\begin{abstract}
The lack of relevant Teacher Education Training Programme (TETP) specifically for economics teachers in Technical Vocational Education and Training (TVET) colleges globally, including South Africa has posed many challenges for teachers. This study reports on the pedagogical challenges of Economics teachers with Postgraduate Certificate (PGCE): Further Education and Training (FET) phase teaching $\mathrm{N}$-level 4 economics in Technical and Vocational Education and Training colleges. The study investigated the pedagogical challenges experienced by economics teachers during the teaching and learning of $\mathrm{N}$-Level 4 economics in one college at Motheo Technical and Vocational Education and Training College. The seven categories of teacher knowledge by Shulman's (1987), underpinned this study. In addition, the pedagogical challenges of Business Studies in secondary schools by Kimotho (2016) serve as a lens to understand the economics teachers' challenges in a Technical, Vocational Education, and Training college. This qualitative research approach used an exploratory case study research design, and selected two economics teachers purposefully and their students who were observed in two different classrooms and later interviewed individually. The findings revealed that the economics teachers displayed five pedagogical challenges associated with content knowledge (CK), curriculum knowledge, pedagogical content knowledge (PCK), knowledge of students, and the interaction with students. Based on the study's limitation, there is a need to identify the educational implications on economics teachers' pedagogical challenges when teaching economics to N-Level 4 students.
\end{abstract}

Keywords: economics; pedagogical challenges; teaching and learning; Technical and Vocational Education; Training teachers

\footnotetext{
*Corresponding author: Msebenzi Rabaza, RabazaM@ufs.ac.za
} 


\section{Introduction}

The Department of Higher Education and Training (2014) report on the European Centre for the Development of Vocational Training (CEDEFOP) identifies the lack of relevant qualifications for Technical and Vocational Education and Training (TVET) teachers globally and in South Africa. The report specifies that TVET colleges have no specific curricula for TVET teachers. Furthermore, the DHET (2014) report also articulates a gap amongst teachers' academic qualifications for TVET colleges in the Free State. In recognising the importance of pedagogical skills, teachers in postsecondary programmes are required to follow some form of pedagogical preparation (Field et al., 2012). This preparation helps the teachers to create and maintain a positive teaching and learning environment where students provide feedback.

The Department of Higher Education and Training [DHET] (2014) states that about $94 \%$ of the TVET teachers are categorised academically into three groups: unqualified teachers, qualified schools teachers (teachers who are academically qualified to teach Grades 1 to 12), and academically qualified teachers (qualified to teach at a TVET college). In the same report, 286 TVET teachers, including teachers of Economics employed at the Free State Public TVET colleges, were underqualified, with 26 teachers (9\%) qualified to teach at TVET colleges. In improving the qualifications of unqualified and academically qualified teachers, the DHET introduced a five-year strategic plan for the capacity building of TVET college lecturers through open learning, in line with the White Paper on Post School Education and Training. The Teaching and Learning Development Sector Reform Forum Contract [TLDSRFC] project was launched in 2015 to develop and strengthen teacher education and to teach in the post-school education and training through the Teaching and Learning Development Capacity Improvement Programme [TLDCIP] (DHET, 2015). The TLDCIP project ended in 2020, with the view that the first TVET qualification will be in place at South African Universities in 2021. Thereafter, the first TVET degree qualification accredited by the DHET in South Africa will be awarded in 2024, and the diplomas in 2023. Hence, we investigated the pedagogical challenges that teachers of Economics with a high school qualification experience when teaching Economics at TVET colleges.

There are limited studies on the pedagogical challenges of Economics teachers at TVET colleges. Hence, Kimotho's (2016) study on the pedagogical challenges Business Studies teachers face and their impact on students' achievement at secondary schools was used. Kimotho's study identified nine pedagogical challenges, namely learning styles and methodology; the nature of students and teaching methodology; classroom diversity; subject matter; context or teaching environment; teachers' awareness of the various teaching and learning methods available; time; the nature of examinations; and the research gap. Kimotho (2016) also identified the pedagogical challenges as a use of traditional teaching methods and insufficient content knowledge (CK) of the subject as affecting the teaching of business studies. However, Business Studies and Economics fall within the commerce discipline. Comparing the results for secondary school and TVET Economics teachers' pedagogical challenges may serve as a basis for the differentiated training required for TVET College teachers teaching Economics. 


\subsection{Research question}

- What are TVET teachers' pedagogical challenges in the teaching and learning of Economics?

\section{Literature review}

\subsection{What is pedagogy?}

There are different definitions of pedagogy, depending on how different researchers view it. For this study, we used a sociological definition of pedagogy. Pedagogy refers to the methods and principles that inform educational techniques and the distinction between what teachers purport to use and the pedagogy observed in practice (Scott, 2014). In this view, when teachers lack the pedagogy to teach at TVET colleges, they may struggle to distinguish what to use when planning for teaching and the actual practice.

Various pedagogical approaches are common in schools, but some strategies are more effective and appropriate than others. However, it is easier for teachers to practise specific pedagogical approaches, such as peer instruction and group learning, in active learning classrooms (Hao et al., 2021). Moreover, connecting different methods and techniques to teach economics concepts may be challenging, especially demand and supply, when teachers lack the relevant qualification. Hence, the study selected two teachers to understand how they teach Economics, what challenges they experience, and the times they experience such challenges.

\subsection{Pedagogical challenges}

This study used Kimotho's (2016) study on pedagogical challenges facing the teaching of the subject Business Studies and their impact on students' achievements in national examinations in Nyandarua, Kenya. The teacher qualifications in Kenya are similar to those of South Africa. Hence, this study used Kimotho's study to explore the pedagogical challenges teachers of Economics experience and the times when these pedagogical challenges manifest when teaching and learning Economics in N-Level 4 classrooms. The discussion and explanation of the nine pedagogical challenges are provided below.

\subsubsection{Learning styles and methodology}

For students to learn meaningfully, a teacher of Economics needs to present the lesson to cater for students with different learning styles. In process terms, learning styles are described as how "students learn in many ways by seeing and hearing; reflecting and acting; reasoning logically and intuitively; memorizing and visualizing and drawing analogies and building mathematical models; steadily and in fits and starts" (Felder \& Silverman, 2002: 1). In emotional terms, Gokalp (2013) refers to learning styles as the fact that every person has his or her method or set of strategies when learning. Significantly, Sarbazvatan et al. (2018) comprehend that understanding students' learning styles is vital, since educational materials and teaching styles strive to fit the students' learning styles, promoting academic achievement. Nonetheless, TVET teachers, without understanding students' learning styles, find themselves struggling to select the relevant methodology to teach Economics to TVET Economics students. However, some studies investigated how undergraduate students of Economics 
focused on their learning styles and concluded that a traditional lecture approach was the dominant teaching method used (Malek, 2010; Leet \& Lopus, 2012). This may also be the case at TVET colleges. Therefore, Economics teachers at TVET colleges need to have relevant knowledge of the students' learning styles to teach Economics so that they understand the concepts. The assumption is that once the teacher knows how students learn, he/she may select a relevant methodology to teach N-level 4 Economics for understanding and apply the knowledge studied.

\subsubsection{The nature of students and teaching methodology}

The Economics teachers at TVET colleges seem not to know much about the students they teach. The lack of understanding the nature of students is due to the focus on chalk and talk teaching that harms students in their learning practice (Ojo \& Jeannin, 2016). Moreover, Kimotho (2016: 31) states that the students of and the teaching methods used to teach Economics need to be investigated to align with the students' abilities. However, students may feel more engaged with their studies if they see that studying Economics can help them unpack the complexities of the world they live in (Ojo \& Jeannin, 2016). In other words, Economics students at TVET colleges taught by means of using chalk and talk may struggle to relate what they have learned about supply and demand to the real world.

Students (passed Grade 12) at TVET colleges may have different teaching and learning needs from high school learners (in Grades 10-12). Therefore, TVET Economics teachers with high school qualifications may struggle to use a differentiated teaching approach that includes designing lesson plans based on students' learning styles, grouping students according to shared interests topics or abilities, and continually assessing and adjusting the lesson content to meet students' needs (Weselby, 2018). For teachers of Economics to meet their students' needs, they need to select the teaching methodology to help them navigate and identify how N-level four students conceptualise economics concepts such as demand and supply with limited pedagogical challenges. Nonetheless, without the relevant TVET teaching qualification, Economics teachers may experience pedagogical challenges when teaching economics.

\subsubsection{Classroom diversity}

There are different views of classroom diversity. For this study, Ottewill (2003) defines student diversity by looking at several characteristics, such as differences between students in terms of the following: their backgrounds and attitudes towards learning; ability in terms of fundamental skills such as numeracy and literacy; and their baseline knowledge of business practices and current affairs. Moreover, employing different methodologies, resources and methods of instruction to cater to these diverse students in one classroom is one of the challenges experienced by Business Studies teachers in Botswana (Sithole \& Lumadi, 2012). In addition, students who grasp the content quickly might get frustrated easily and hold back if mixed with students who are slower to grasp the content (Sithole \& Lumadi, 2012), which requires the teacher's flexibility to organise the lesson in ways that accommodate diverse learners. This burden rests heavily on the teacher attempting to create a teaching environment that will benefit students with different abilities. Working to meet a classroom's diverse 
needs and abilities might be a daunting task for teachers of Economics. Uddin and Johnson (2018) found that student bodies on campuses around the country reflect significant variations in culture, ethnicity, social and emotional health, and socioeconomic conditions. Therefore, attempting to meet these students' needs requires that teachers develop an awareness of and explicitly respond to these ethnic, cultural, social, emotional, and cognitive characteristics.

\subsubsection{Subject matter knowledge for teaching}

One of the critical aspects of teaching Economics is the subject matter knowledge (SMK) that teachers of Economics need to help TVET Economics students understand specific concepts, such as supply and demand. Davidowitz and Rollnick (2011) have identified the place of SMK in PCK as related to the domains of teacher knowledge. At the same time, Shulman (1987) places subject matter in CK. Shulman further states that teachers must define the concepts for students and the accepted truths in a domain must explain why a particular proposition is warranted. Moreover, it is worth knowing how the subject matter knowledge relates to other propositions within the discipline and out of the discipline, both in theory and practices (Shulman, 1987). Therefore, TVET teachers of Economics need to possess the subject matter knowledge relevant to teaching specific concepts in economics, such as demand and supply, and go deeper and broader when planning and presenting the lesson. In other words, TVET teachers of Economics' subject matter knowledge needs to be developed for teaching in high schools and help teachers when teaching demand and supply concepts, such as descriptions of shortages and surplus and the calculation thereof (Paterson et al., 2017). Moreover, Economics student teachers at higher education institutions may not have the same subject matter as the content syllabus at TVET colleges. Therefore, if the student teachers are prepared to teach in the FET phase and are then employed to teach at a TVET colleges, the latter may have the same subject matter knowledge, but the articulation of subject matter knowledge may be inevitable without a well a developed pedagogical knowledge.

\subsubsection{Knowledge of educational contexts}

Knowledge of educational contexts is vital for N-Level 4 teachers of Economics at TVET colleges and to identify ranges from the workings of the group or classroom, the governance, and financing of school districts to the character of communities and cultures (Shulman 1987: 8). Without understanding the educational context, teachers of Economics may experience a pedagogical challenge when they include the levels of responsibility, the students' social, religious, and cultural backgrounds when teaching N-Level 4 Economics. In addition, it will be beneficial for the TVET Economics teacher to know how the TVET college operates, its governance, and the financial implications of the college. Since they may have examples of challenges from their context and relate to the adequacy of teaching resources (Sithole \& Lumadi, 2012).

One asks whether the teachers of Economics at TVET colleges relate their teaching of economics to the context. If so, to what extent do TVET teachers lack an understanding of context in relation to economics teaching? The study by Lumadi (2012) further reports that teaching and learning have stopped at some colleges because of several inefficiencies. Hence, Shulman (1987) states that one aspect of 
knowledge of the educational context involves the socioeconomic level of the surrounding area, the type and size of the school, the class size, and the amount of quality support teachers and other colleagues provide to one another. Without this knowledge, teachers of Economics might not teach economics by relating it to the TVET surroundings. These are some of the many general challenges that teachers of Economics face daily. Moreover, Badenhorst and Radile (2018) state that the vocational systems suffer from inadequate partnerships with the business sector. The lack of partnership may result in teachers of Economics having inadequate knowledge of the context they teach, and it becomes difficult for teachers to provide examples in class when teaching a specific concept such as demand and supply.

\subsubsection{Teachers' awareness of the various teaching-learning methods available}

Teachers of Economics may have an awareness of the different teaching and learning methods to teach economics. However, Zanca (2017) has found that teachers of Economics still use lecture methods to teach economics. In contrast, Gullason (2009), Di Libedo (2010), and Umar et al. (2016) assert that economics as a social science requires teaching that is learner centred. In this view, Di Libedo (2010) indicates that there seems to be resistance from teachers of Economics to shift from the instruction paradigm to the learning paradigm. However, a lack of training or the amount of work in the learning paradigm may prevent this shift. There may be various teaching methods available to teachers of Economics, although there is still much debate about which method is best for economics teaching at TVET colleges. Learner-centred teaching approaches such as groupwork, interactive learning activities, and adaptive instruction have been identified as relevant for TVET teaching (CEDEFOP, 2015). The benefits are associated with students' motivation and engagement, learner satisfaction, dropout rates, and retention. The CEDEFOP (2015) advocates learner-centred pedagogies and discourages traditional teaching methods at TVET colleges, due to students' roles when they leave TVET colleges.

\subsubsection{Allocated time for economics teaching}

The DHET (2021) highlights in the 2021 teaching and learning plan that sufficient time is allocated per subject in all the programmes. One would argue about the measure for sufficient time, since there are diverse learners in the classroom. Therefore, an adequate time for one learners may be inadequate for the other though they would be in the same classroom. Moreover, the DHET (2018) states that for Semester 1, there are approximately 85 lecturing days for semester modules, which amounts to 17 weeks. There are four periods allocated for Economics in Motheo TVET College, and each lasts for $1 \frac{1 / 2}{2}$ hours to make a total of six hours a week. For example, the Economics N-level 4 syllabus is divided into six modules to be completed within 12 weeks, with four weeks for a formal assessment, resulting in 16 full weeks for the semester.

\subsubsection{The nature of examinations}

The nature of the examination was not relevant for this study, though it was found in Kimotho's study since the study was longitudinal. This aspect was deemed not sufficient for teaching and learning at a TVET college. 


\subsubsection{Research gap}

Research has been conducted on teaching approaches for economics at schools and for undergraduate studies (Becker \& Watts, 1995; Malek, 2010), and few studies focus on the teaching and learning of economics globally and at the South African TVET colleges. There is a need to conduct research globally and in South Africa on the teaching and learning of economics at TVET colleges.

\subsection{Theoretical framework}

This study's theoretical framework used the lenses of Shulman's (1987) seven categories of teacher knowledge, which includes, Content Knowledge (CK), General pedagogical knowledge, Curriculum knowledge, Pedagogical content knowledge (PCK), Knowledge of learners and their characteristics, Knowledge of educational contexts, and Knowledge of educational ends. Below is an explanation of each category of teacher knowledge. CK refers to the awareness of the facts and the structure of their subject/s (Niemelä \& Tirri, 2018). GPK refers to understanding what counts as good teaching and the best teaching approaches in a given context informed by knowledge of applicable learning theories (Rollnick et al. 2008). Thirdly, Curriculum knowledge includes awareness of various instructional materials, teaching procedures, and learning objectives (Niemelä \& Tirri, 2018). The TVET Economics curriculum is not the same as the secondary school Economics syllabus. Fourthly, Berry et al. (2016) argue that PCK is assumed to synthesize and integrate all known elements needed for influential teachings, such as pedagogy, subject matter knowledge, student characteristics, and environmental context teaching and learning. In the fifth instance, learners' knowledge and characteristics are classified into two categories namely, social and cognitive knowledge of learners (Baynham \& Frank, 2021). Social knowledge of learners refers to how learners of a particular age are like their behaviour, interests, and preoccupations, whereas cognitive knowledge of learners refers to their development that informs practice and knowledge context-bound to a particular group of learners (Baynham \& Frank, 2021). The development of PCK is influenced by factors related to the teacher's background and the context in which he or she works (Solís, 2009). Hence the economics teacher needs to know educational contexts. A seventh point is knowledge of educational ends that refers to the purposeful activity of teaching time both in short-term goals example, a lesson or several lessons, and a long-term purpose of education (Green \& Leask, 2013). Although all the categories of teacher knowledge involve aspects of teaching, they help to identify the complexity of their interaction in the teaching of N-Level 4 Economics at a TVET college.

\section{Methodology}

This qualitative research study used an exploratory case study research design to explore a real-life, contemporary bounded system (a case) or multiple bounded systems (cases) over time through detailed, in-depth data collection involving multiple sources of information and reports a case description and case themes (Creswell, 2013). A purposive sampling technique selected two TVET teachers of Economics at one TVET college who taught 62 students, 30 and 32 students in Class A and B, respectively. A self-developed observation manual and structured individual interview schedule were sent to colleagues at the University for 
Content Validity. The comments and suggestions received on each section with the piloted instruments were amended accordingly. Data were collected from two teacher observations and two individual interviews with the participants separately. The participants taught the demand and supply concepts during the lesson observation. Both lesson observations lasted approximately an hour and 30 minutes each, and the individual interviews lasted approximately 30 minutes for each teacher. The ethical clearance number UFS-HSD2018/1627/0905 was obtained in compliance with the ethical considerations and pseudonyms such as teachers (Ann and Lethlo) referred to the participants.

\section{Findings and discussion}

The data from the observations and individual semi-structured interviews were analysed thematically. The data were organized into one theme and presented as the results below.

\subsection{List of pedagogical challenges}

Data from the lesson observations and interviews revealed a list of five pedagogical challenges, CK, curriculum knowledge, PCK, knowledge of students, and the interaction with students is explained below:

\subsubsection{Content knowledge}

The paragraph below discusses the participants' CK by looking at the two categories, prior knowledge associated with the concept taught, and the concepts and sub-concepts that form part of supply and demand.

Both participants did not appreciate the students' prior knowledge of supply and demand when teaching N-level 4 students. The participants requested the students to open their textbooks and to start reading, which suggests that both teachers had a challenge in planning the lesson and accommodating the students' prior knowledge of the concepts taught. To be effective, teachers need to tap into students' prior knowledge that needs to be addressed as they come with it to the classroom (Darling-Hammond \& Oakes, 2021). Furthermore, if their knowledge and beliefs are not engaged, students may fail to grasp new concepts and information taught. This suggests that meaningful learning has not taken place.

When the participants were asked whether they possessed the content knowledge relevant to $\mathrm{N}$-Level 4 economics during the individual interview session, their responses showed adequate content knowledge for teaching economics at a TVET college; therefore, the participants' responses on content knowledge as highlighted below.

Ann response, "I think I have enough content knowledge because I used to teach economics in the secondary school, and the syllabus is the same."

Lethlo - "I have sufficient knowledge. The content in N4 economics is not different from secondary economics.

Though the two participants felt that the content is the same as the CK for secondary school economics, there may be some differences. Their responses showed that the level at which they presented N-level 4 economics concepts is not 
higher than secondary school level. The researchers observed that both teachers presented different concepts when teaching economics. Both teachers followed the concepts and sub-concepts highlighted from the textbook, such as demand and supply, the law of demand and supply, factors that determine the quantity demanded and supplied, plotting the demand and supply curve, the slope of the demand and supply curve, and changes in supply and demand. This suggests that the textbook supported the participants' CK adequately.

However, the researchers observed that both teachers relied on textbooks when teaching supply and demand concepts. The interview responses contrasted with the practical lesson; the knowledge of content could not be identified due to reliance on the textbook. This suggests that both teachers experienced a pedagogical challenge concerning the $\mathrm{CK}$ for teaching demand and supply. Kimotho's (2016) study agrees with this finding that insufficient content knowledge affects the teaching of business studies, which may be the case in $\mathrm{N}$ Level 4 economics.

\subsubsection{Curriculum knowledge}

Participants' knowledge of the curriculum is organised into two categories: awareness of learning objectives, and awareness of teaching and learning materials. Knowledge of the learning objectives is understood as mathematics teachers' knowledge about planning, organising, and presenting a specific topic to achieve the learning outcomes. At the same time, the awareness of the teaching and learning material is understood as the representations that help the economics teacher to complement verbal with non-verbal explanations.

Regarding the awareness of the learning objectives, it was not clear what the participants wanted the students to achieve at the end of teaching demand and supply concepts based on the observation. Mitchell and Manzo (2018) state that much of the existing assessment and instructional design strategies revolve around learning objectives. Moreover, instructional designers argue that learning objectives provide a focused mindset for students engaging in the content. Therefore, it may be challenging to focus students on achieving a planned lesson's objectives without a focused lesson plan. Hence, the participants failed to achieve to direct students into achieving something in the lesson.

When the participants were asked during the interview about the guide to teach demand and supply in Economics, their responses showed that they were not happy with the same curriculum for different educational levels. The responses of the two participants are presented below.

Ann - the syllabus is outdated, and the textbook does not have all the related content for Economics N4.

Lethlo - the textbook needs no change, but the syllabus can be updated, since it is the same as the secondary school Economics syllabus.

Both participants' highlighted the textbooks and the curriculum as not relevant for N-level 4 economics, though they were identified as relying on textbooks when teaching. This suggests that the participants' awareness of the curriculum was 
inadequate. Bell (2015) agrees that the the accuracy of delivering content to students is affected by the lack of training or guidance on the curriculum. Hence, teachers struggle to organise the teaching materials to suit the learning objectives of economics concepts such as demand and supply.

\subsubsection{Pedagogical content knowledge}

The PCK is discussed and looked at in three categories: linking prior knowledge with new knowledge, representing an explanation to cater for students' learning styles, and using teaching approaches to help students learn. The instructional models used by teachers can provide students with meaningful learning experiences such as reading, connecting prior knowledge to new information learned in the classroom, and doing investigation-based, discussion and evaluation activities (Saenab et al., 2021). At the same time, the teachers' ability to present an explanation demand and supply concepts by catering for students' learning styles in N-Level 4 Economics were not visible during the observation. The teachers can use representations to help students make sense of the concepts, demand and supply. The teachers' ability to use the teaching approaches and strategies flexibly to organise the teaching and learning activities for learners to learn meaningfully according to their own pace.

Both teachers did not take the opportunity to get feedback from the students on what they already knew about the concepts of demand and supply. Instead, the participants taught $\mathrm{N}$-Level 4 economics following a textbook method. The finding suggests that the teachers had a challenge to organise the lesson to accommodate the feedback from the students.

Both teachers of Economics struggled to use representations to create a mental image for students when explaining supply and demand concept, directing students to the textbooks while reading for them. However, Quecan (2021) asserts that it is challenging to understand images presented in a textbook that typically represents one culture. Using representations from the students' environment that relate to the concept taught will help students to engage and learn. The participants taught the lessons through verbal explanation examples, spoken and written text through whiteboard markers and whiteboard.

\subsubsection{Knowledge of students}

The knowledge of students is categorised into two sociological and educational aspects. The sociological aspects include the teachers' ability to know students' family matters that affect the teaching and learning of economics concepts. The educational aspects include the teachers' ability to know which concepts the students find challenging and how students learn.

During the interview session, when teachers were asked about their knowledge of the students they teach, their responses displayed inadequate knowledge of students, and they even blamed the students' backgrounds for their inadequate knowledge. During the observed lessons, the teachers displayed no knowledge of the students. Supporting this, teachers stated the following: 
Ann - "I have no knowledge of my students' background. I sometimes think they have no religious background because they are so ill-disciplined."

Lethlo - "I feel as teachers we do not have enough information on the students' background because I have students in my classroom who are from very poor backgrounds but only realise that when they tell me that they could not attend class because of lack of money for transport."

The academic aspects displayed during the observations in the classroom related to students' knowledge were minimal and negative. When both teachers asked the questions to the students, the students' responses were either correct or incorrect and the teacher moved to the next part of the lesson. Nevertheless, the teachers' awareness of motivation and the ability to develop a relationship with the students in the teaching process provide a framework by which the teacher can choose effective teaching methods (Halim et al., 2019). Without an awareness of how learners learn, teachers of Economics may struggle to assist students in learning economics.

\subsubsection{Interaction with students}

The interaction of teachers of Economics with their students is categorised into teacher and content, and teacher and students. The content and teacher interaction is the ability of the economics teacher to organise, simplify and present the economics concepts to engage students in a meaning-making process. The teacher and student interaction is the teacher's ability to create space for both students and their teacher to form a relationship through verbal and non-verbal communication about the content in the classroom.

Two participants interacted with the content by reading from the textbooks and writing on the whiteboard, drawing the demand and supply graphs. Both teachers did the talking and ask whether students were still with them or not. Interaction with students provides an opportunity for thinking and analysis, uses feedback from students effectively to guide students' thinking by extending to the students' prior knowledge (Rimm-Kaufman \& Sandilos, 2010). This suggests that both teachers had pedagogical challenges with student interaction, which led to limited interaction with no feedback from the students to show how much they have learned.

\section{Conclusion}

The findings of this study suggest that the five pedagogical challenges displayed by the teachers of Economics at one campus of Motheo TVET College could be associated with lack of relevant TVET qualification. Moreover, the teachers' pedagogical challenges affect the students' learning for understanding N-level 4 economics. The participants' responses showed that the continuous impact of the pedagogical challenges results in non-interactive students in N-level 4 economics classrooms. They were observed as struggling to interact with students to develop a conducive environment for students to learn. Alongside that, their content and curriculum knowledge appear inadequate, with reliance on the textbooks for 
examples and drawings of the demand and supply graphs. Based on the findings, it could be concluded that N-level 4 teachers of Economics at one college of Motheo TVET had pedagogical challenges that relates to $\mathrm{CK}$, curriculum knowledge, PCK, knowledge of students, and the way to interact with the students. These pedagogical challenges need to be overcome to help teachers support students learning of N-level 4 economics. These categories are assumed to support Shulman's categories of teacher knowledge (1987) and validate the attributes of PCK to overcome the pedagogical challenges (Kimotho, 2016).

\section{Implications}

It can be seen from this study that the pedagogical challenges experienced by the N-level 4 teachers of Economics could contribute meaningfully to the development of a relevant teaching qualification for TVET teachers of Economics. According to UNESCO (2014), Quality TVET teachers have both expert knowledge in their field and can transfer this knowledge to their students. Hence, it is essential for teachers of Economics to link their expert knowledge with the current knowledge in the field, provide relevant representations, and help students to learn meaningfully. Several studies tapping into pedagogical knowledge and challenges indicate that these change over time. Hence more research should investigate this. The current study attempted to investigate the pedagogical challenges in teaching $\mathrm{N}$-Level 4 economics by observing teachers in class and interviewing them after class. This study hopes to add more insights to the less-explored areas of teacher competence, specifically teachers' pedagogical challenges when teaching N-Level 4 economics.

\section{References}

Badenhorst, J. W., \& Radile, R. S. (2018). Poor performance at TVET Colleges: Conceptualising a distributed instructional leadership approach as a solution. Africa Education Review, 15(3), 91-112. https:/ / doi.org/10.1080/18146627.2017.1352452

Baynham, J., \& Frank, H. (2021). The professional knowledge of teachers. In M. Hulme, R. Smith \& R. O'Sullivan (eds), Mastering teaching: Thriving as an early career teacher (pp. 60-67). Open University Press.

Becker, W. E., \& Watts, M. (1995). Teaching tools: Teaching methods in undergraduate economics. Economic Inquiry, 33(4), 692-700. https://doi.org/10.1111/j.14657295.1995.tb01889.x

Bell, H. (2015). The dead butler revisited: Grammatical accuracy and clarity in the English primary curriculum 2013-2014. Language and Education, 29(2), 140-152. https://doi.org/10.1080/09500782.2014.988717

Berry, A., Depaepe, F., \& Van Driel, J. (2016). Pedagogical content knowledge in teacher education. In J. Loughran \& M.L. Hamilton (eds), International Handbook of Teacher Education (pp. 347-386). Springer. https:/ / doi.org/10.1007/978-981-10-0366-0_9

Creswell, J. W. (2013). Qualitative Inquiry and Research Design. Choosing among Five Approaches. SAGE.

Darling-Hammond, L., \& Oakes, J. (2021). Preparing teachers for deeper learning. Harvard Education Press.

Davidowitz, D., \& Rollnick, M. (2011). What lies at the heart of good undergraduate teaching. A case study in organic chemistry. Chemistry Education Research and Practice, 12, 355-366. http://dx.doi.org/10.1039/C1RP90042K 
Department of Higher Education and Training [DHET]. (2014). Qualification profile of lecturers employed in public Technical Vocational Education and Training Colleges in South Africa. https://www.dhet.gov.za/Outcome/DHET\%202014\%20TVET\%20 Lecturer\%20Qualifications\%20Profile\%20Report.pdf

Department of Higher Education and Training (DHET). (2015). Business Plan: Teaching and learning development sector support programme. https:// www.dhet.gov.za/SiteAssets/ Latest\%20News/2018/Business\%20Plan\%20(TLDSSP).pdf

Department of Higher Education and Training (DHET). (2018). Technical and Vocational Education and Training (TVET) College calendar 2018, Report 191: Natural sciences studies. https://www.dhet.gov.za/Technical\%20and\%20Vocational\%20Education\%20a nd\%20Training\%20Co/TVET\%20College\%20Calendar\%202018.pdf

Department of Higher Education and training [DHET]. (2021). Teaching and learning plan 2021: Technical and Vocational Education and Training (TVET) colleges. https:// www.dhet.gov.za/Technical\%20and\%20Vocational\%20Education\%20a nd\%20Training\%20Co/2021\%20Teaching\%20and\%20Learning\%20Plan.pdf

Di Libedo, M. J. F. (2010). How students learn economics and the importance of real-life examples. Northeast Business and Economic Association, XXX, 660-666.

European Centre for the Development of Vocational Training [CEDEFOP]. 2015. Vocational pedagogies and benefits for the learner: Practices and challenges. https://www.cedefop.europa.eu/files/5547_en.pdf

Felder, M., \& Silverman, L. K. (2002). Learning and teaching styles in engineering education. Enineering Education, 78(7), 674-681. https:/ / www.engr.ncsu.edu/wpcontent/ uploads/drive/1QP6kBI1iQmpQbTXL-08HSI0PwJ5BYnZW/1988-LSplus-note.pdf

Field, S., Álvarez-Galván, J. L., Hénard, F., Kis, V., Kuczera, M., \& Musset, P. (2012). A skills beyond the school review of Denmark. OECD publishing. http://dx.doi.org/10.1787/9789264173668-en

Gokalp, M. (2013). The effect of student's learning styles to their academic success. Journal of Creative Education, 4(10), 627-632. https:/ / doi.org/10.4236/ce.2013.410090

Green, A., \& Leask, M. (2013). What do teachers do? In S. Capel, M. Leask \& T. Turner (eds), Learning to teach in the secondary school: A companion to school experience ( $3^{\text {rd }}$ ed., pp. 9-24). XXX: Routledge.

Gullason, E. T. (2009). A compilation and synthesis of effective teaching strategies in the economics discipline. Journal of Business and economics, 15(2), 83-96.

Halim, S., Wahid, R., Halim, T., \& Farooq, O. (2019). Why don't learners learn what teachers teach? Language in India. www.languageinindia.com

Hao, Q., Barnes, B., \& Jing, M. (2021). Quantifying the effects of active learning environments: separating physical learning classrooms from pedagogical approaches. Learning Environments Research, 24, 109-122. https:// doi.org/10.1007/s10984-020-09320-3

Kimotho, R. M. (2016). Pedagogical challenges facing the teaching of business studies and impact on students' achievement in secondary schools in Nyandarua. Unpublished Master's dissertation, Kenyatta University, Kenya. Semantic scholar. https://www.semanticscholar.org/paper/Pedagogical-challengesfacing-the-teaching-of-andKimotho/e76affaaeb9e9762ed3e4074f260966439044256

Leet, D. R., \& Lopus, J. S. (2012). Tips for teaching the high school economics course. Social Studies Research and Practice, 7(1), 9-18. https://www.proquest.com/docview/ 235802939? pq-origsite $=$ gscholar\&fromopenview $=$ true 
Malek, N. P. (2010). Three Essays in Economics Education: An overview of the research and two studies on the effectiveness of alternative teaching methods and the influence of ethics in the classroom on economics knowledge and political philosophy. Dissertation, George Mason University, Fairfax, VA. ProQuest LLC. https://eric.ed.gov/ ?id=ED517516

Mitchell, K. M. W., \& Manzo, W. (2018). The purpose and perception of learning objectives. Journal of Political Science Education, 14(1), 1-17. https://doi.org/10.1080/15512169.2018.1433542

Niemelä, M. A., \& Tirri, K. (2018). Teachers' Knowledge of Curriculum Integration: A Current Challenge for Finnish Subject Teachers. In Y. Weinberger, \& Z. Libman (eds.), Contemporary pedagogies in teacher education and development (pp. 119-132). IntechOpen. https://doi.org/10.5772/intechopen.75870

Ojo, E., \& Jeannin, L. (2016). The way economics is taught needs an overhaul: A South African case study. Unpublished master's dissertation, Johannesburg, University of the Witwatersrand. WIREDSPACE. https:// businesstech.co.za/news/finance/145109/the-way-economics-istaught-needs-an-overhaul-a-south-african-case-study/

Ottewill, R. (2003). Pedagogic challenges facing business and management educators: Assessing the evidence. International Journal for Management Education, 3, 33-41. https://eprints.soton.ac.uk/11119/

Paterson, A., Keevy, J., \& Boka, K. (2017). Exploring a Work-Based Values Approach in South African TVET Colleges to Improve Employability of Youth: Literature review. https://www.jet.org.za/unevoc/jet-tvet-resources/exploring-a-work-basedvalues-approach-in-south-african-tvet-colleges-to-improve-employability-ofyouth-literature-review

Quecan, L. (2021). Visual aids make a big impact on ESL students: A guide for ESL teachers. Master's Dissertation, University of San Francisco, San Francisco. Geschke Center. https:/ / repository.usfca.edu/capstone

Rimm-Kaufman, S., \& Sandilos, L. (2010). Improving students' relationships with teachers to provide essential supports for learning: positive relationships can also help a student develop socially. https://www.apa.org/education/k12/relationships

Rollnick, M., Bennett, J., Rhemtula, M., Dharsey, N., \& Ndlovu, T. 2008. The place of subject matter knowledge (PCK): A case study of South African teachers' teaching the amount of substance and equilibrium. International Journal of Science Education, 30(10), 1365-1387. https:// doi.org/10.1080/09500690802187025

Saenab, S., Zubaidah, S., Mahanal, S., \& Lestari, S.R. (2021). ReCODE to Re-Code: An instructional model to accelerate students' critical skills. Education Sciences, 11(1), 1-14. https://doi.org/10.3390/educsci11010002

Sarbazvatan, H., Amini, A., Aminisani, N., Shamshirgaran, S., \& Ghaffarifar, S. (2018). Learning styles and academic achievement among students at Tabriz University of Medical Science, Iran. Research and Development in Medical Education, 7(2), 77-81. https://rdme.tbzmed.ac.ir

Scott, J. (2014). A dictionary of sociology, $4^{\text {th }}$ edition. Oxford University Press. https://www.oxford reference.com/view/10.1093/acref/9780199683581.001.0001/acref9780199683581

Shulman, L. S. (1987). Knowledge and teaching: Foundations of the new reform. Harvard Educational Review, 57(1), 1-23. https://doi.org/10.17763/haer.57.1.j463w $79 \mathrm{r} 56455411$ 
Sithole, B. M., \& Lumadi, M. W. (2012). Pedagogical challenges besetting business studies teachers in secondary schools: A Botswana perspective. Journal of Social Sciences, 32(1), 71-80. https://doi.org/10.1080/09718923.2012.11893053

Solís, A. (2009). Pedagogical content knowledge - what matters the most in the professional learning of content teachers in classrooms with diverse student populations. https://www.idra.org/resource-center/pedagogical-contentknowledge/

Uddin, M. M., \& Johnson, K. V. (2018, June), Identifying classroom management strategies by focusing on diversity and inclusion [Paper presentation]. 2018 ASEE Annual Conference \& Exposition, Salt Lake City, Utah. https:/ / peer.asee.org/30593

Umar, M. A., Dauda, B., \& Mutah, L. K. (2016). Effectiveness of demonstration and lecture methods in learning concepts in economics among secondary schools students in Borno State, Nigeria. Journal of Education and Practice, 7(12), 51-59. https:// files.eric.ed.gov/fulltext/EJ1099610.pdf

UNESCO (2014, May 12-26). Vocational pedagogy: What it is, why it matters and how to put it in practice. UNESCO-UNEVOC International Centre for Technical and Vocational Education and Training. https://unevoc.unesco.org/fileadmin/up/e-forum_ synthesis_report_on_vocational_pedagogy.pdf

Weselby, C. (2020). What is differentiated instruction? Examples of how to differentiate instruction in the classroom. https://resilenteducator.com/classroomresources/examples-of-differentiated-instruction/

Zanca, N. A. (2017). Lecture vs. lecture-less: A meta-analysis from journal of economics education (1969 to 2016). Journal of Economics Insight, 43(2), 69-93. https://ideas.repec.org/a/mve/journl/v43y2017i2p69-93.html 